International Journal of English Literature and Social Sciences
Vol-7, Issue-1; Jan-Feb, 2022
Journal Home Page Available: https://ijels.com/
Journal DOI: $10.22161 /$ ijels

Peer-Reviewed Journal

\title{
HUNGER: The Seed of Society's Service Sterility
}

\author{
Akshara Gera
}

Law Student, Jindal Global Law School, India

Email: aksharagera@gmail.com

Received: 15 Dec 2021; Received in revised form: 23 Jan 2022; Accepted: 01 Feb 2022; Available online: 09 Feb 2022

C) 2022 The Author(s). Published by Infogain Publication. This is an open access article under the CC BY license

(https://creativecommons.org/licenses/by/4.0/).

\begin{abstract}
This paper about the one of the saddest worldwide phenomenon "Hunger", relates to an individual's productivity. The paper sheds light upon the basics of the topic "Hunger", and its geographical effects on the productivity of humans, and how as per the different adaptation of the same circumstances by individuals causes different results, which are in direct contradiction with the assumptions and statistics.
\end{abstract}

Keywords—Developed Countries, Developing Countries, Hunger, Productivity.

\section{INTRODUCTION}

As Sathya Sai Baba once said, "The gift of food to the hungry is the noblest of all gifts."

To ponder upon how a tiny part of our daily lives like having our food received on a plate or getting it delivered by Zomato if given to someone else might bring out their tears is heart-warming yet sad at the same time. Such is the issue of hunger! The word used daily in our happy lives is a worldwide huge problem with millions suffering from it and that too for days on a very common basis.

Hunger is not just a craving for food or lack of food, it is also the discomfort that is caused by these long periods when a person stays without food, which then affects the health of the person directly.

\section{THE PROBLEM WORLDWIDE}

As basic as the need for food, food is no less than a human right, and for a human to be deprived of the human right itself is not acceptable. Every thirteen seconds, hunger becomes the reason for a child's death in the world of 811 million people who stay hungry and over 2 billion worldwide are prey to malnutrition.

Moving on to measure the global hunger index to help measure the situation of hunger according to different geographical locations. As per the year 2021, 18 countries have a score less than 5, depicting low levels of hunger, as the higher the score the worse the situation is. 12 out of these 18 countries are from Europe, implying Europe's success when handling this issue. India on the other hand comes among one of the last countries with a score as high as 27.5 , and Somalia being in the worst state with a score of 50.8, the highest of all.

Since the intensity and widespread is very evident about the issue of hunger, it not only affects the person's health, it also affects the country at large and more problems occur which the article will shed light upon next.

\section{DIFFERENT FORMS OF HUNGER}

When someone thinks of hunger, the pictures of a kid on land affected by drought come to mind, but what is left behind is the other arms of this beast named hunger. The undernourishment for a short period with the extreme form of hunger is acute hunger, whereas the long-term undernourishment caused by the lack of intake of required nutrition is chronic hunger. Acute hunger is usually caused by an environmental crisis like drought and chronic hunger is caused by poverty as these individuals do not have enough money to access a properly balanced diet or clean water.

Moving to hidden hunger, which is worst of all as this act as a slow poison to the body and is not even visible, and can be only spotted later on in life when the unbalanced 
diet causes a lack of required nutrients in the body resulting in the development of serious diseases physically and affecting the development of the human even mentally.

\section{THE RELATIONSHIP OF PRODUCTIVITY AND HUNGER}

The word "Hangry" itself says a lot about your feelings when feeling hungry, that irritation, that annoyingness, that not in a mood to do anything. It is all because when an individual is not satisfied with their food intake, the mind is unable to focus enough on anything else. Especially the fluctuating levels of blood sugar caused by the gaps between food intake cause lower productivity of an individual. Just by the understanding of these limited facts, one can assume how this lack of productivity would in long term affect the economic growth of that particular country, too.

When connecting hunger with productivity, consideration of the type of hunger is the basic need to try to come to the most accurate possible conclusions. A person going through acute hunger obviously cannot work at all, as the levels of their physical and mental capacity reach rock bottom, making it difficult to even survive, and productivity is no priority at that time. Whereas when a person is a prey to chronic hunger and hidden hunger, things start to change.

\section{GEOGRAPHICAL EFFECTS}

Even the very basic and common phenomenon of hunger has widely different impacts on different individuals. This different impact is governed highly by varied factors, one of which is the geographical location. As per the status of the country, people living in developing and developed countries act, react and think differently about the very same thing, and even in the same situation and circumstances sometimes.

Talking of developing countries, the individuals even though are sufferers of malnutrition and are undernourished they tend to adapt and cover the food energy to physical work. This is more likely to happen in developing countries, compared to developed countries. This adaptation of working with less diet comes along with a catch called insufficiency to cope with any kind of additional stress, hence restricting their work to a certain limit, which is mostly physical. One might say that due to the adaptation these developing countries do not show the low productivity that can occur, but they are called developing for a reason, the lack of hunger fulfillment might not cause any kind of endemic starvation or any kind of restricted economic productivity, but behind the sheets the low intake of the required nutrients which one might miss counting as hunger causes restrictions.

\section{THE EXCEPTION CONTRADICTION}

Even though there have been arguments about the opposite, stating that hunger allows a person to be more productive sometimes, but to think about it, there exist a few conditions for the same, as the humans suffering through these conditions are more prone to adopting the circumstances than making a variation or letting it affect them. On a personal note, my grandmother says, "Anything's possible only if you have the willpower to do it", seems like she is right, as even though one can infer that since Yemen and Somalia has a score as high as 45.1 and 50.8 respectively on the global hunger index and have an extreme GDP of around 23.5 billion USD and 5 billion USD, the hunger has a great effect on productivity directly and hence, the economic growth. But when compared with a country like India, which even though comes among the countries with the highest global hunger index with a score of 27.5 , it even comes among the countries with one of the highest GDPs, with a GDP of around 262 trillion USD! This fact directly contradicts one's conclusion of the connection.

\section{CONCLUSION}

With contradictions and no direct conclusion coming up in the understanding of this relationship, it can be said that the recommendations and ways designed to measure the situations are not solid enough and are often misinterpreted by agencies and researchers. The focus is needed on different subjects too, as food intake might be the one ruling the world of measurements and understanding of the issue, but the topic of quality of food intake requires more attention and focus. Ending the article by stating that no matter how much one studies the connection of productivity and hunger, energy levels might be understood with food science but understanding the issue of hunger is never possible. Going by the lines of Mr. Pandurang Vasudeo Sukatme, relating the energy needs of humans to understand the complexity of human health is unwise and immoral.

\section{ACKNOWLEDGEMENTS}

I'd just like to express my gratitude towards the almighty God and pray for the better circumstances of this little mortal world.

\section{REFERENCES}


[1] Hunger - facts \& figures. Welthungerhilfe.de - Für eine Welt ohne Hunger und Armut. (2021). Retrieved February 4, 2022, from https://www.welthungerhilfe.org/hunger/

[2] Edmundson, W. C., \& Sukhatme, P. V. (1990). Food and Work: Poverty and Hunger? Economic Development and Cultural Change, 38(2), 263-280. http://www.jstor.org/stable/1154026

[3] GDP by country. Worldometer. (n.d.). Retrieved February 4, 2022, from https://www.worldometers.info/gdp/gdp-bycountry/

[4] Global hunger index. globalhungerindex.org. (2022). Retrieved February 4, 2022, from https://www.globalhungerindex.org/pdf/en/2020.pdf 